\title{
FORMAL ASPECTS OF FRENCH NONLEXICAL DATIVES*
}

JOHAN ROORYCK

\section{LEXICAL AND NONLEXICAL DATIVES1}

As Barnes (1985) remarks, traditional grammar considers the French dative clitic pronouns in (1) as substitutes attached to the verb for prepositional complements of the animate type introduced by the preposition $\dot{a}$. Instances of this correspondence are exemplified in (2).

(1) me (1sg.) te (2sg.) lui (3sg.) nous (1pl.) vous (2pl.) leur (3pl.)

(2) a. Je lui donne le livre. 'I give him/her the book' Je donne le livre à Marie.

b. Elle lui ressemble beaucoup. 'She resembles him/her a lot.' Elle ressemble beaucoup à sa mère.

A first problem for this approach are sentences with noncliticizable $\dot{a}-N P$.

(3) a. Je pense à Anatole. 'I'm thinking of Anatole.' *Je lui pense. I, Je pense à lui.

b. T'u devras l'habituer à ton père.

'You'll have to get him used to your father.'

*Tu devras le lui habituer. ', .r'u devras l'habituer à lui.

Barnes (1985) refers to her 1980 article which explains these cases by "semantic implications which always attach to the dative clitic" (Barnes (1985: 160)). We will not go into this problem here. Let it suffice to refer to an alternative and more formalized explanation 
for noncliticizable $\dot{a}-N P$ that has been proposed by Blanche-Benveniste et alii (1984: 43-44) in an altogether different framework. The authors explain the differences between cliticizable and noncliticizable $\dot{a}-N P$ by a subcategorization hierarchy among the syntactico-semantic features of the dative position.

The second problem for the traditional analysis, which will concern us here, is the existence of nonlexicalizable dative clitics, or at least lexicalized dative clitics that are not fully grammatical in Standard French.

(4) a. Je lui ai trouvé un emploi. 'I found him/her a job.'

? J'ri trouvé un emploi à Théophile.

b. Le gosse lui a démoli son pull. 'The kid destroyed his sweater.' ?? Le gosse a démoli son pull à sa mère.

c. Elle lui a tiré dans le ventre. 'She shot him in the stomach.' * Elle a tiré dans le ventre à Jean.

Barnes (1985) calls this last type of dative nonlexical as opposed to the lexical datives of (2). She sides with Leclère (1978), who defines a lexical dative verb as a verb that is subcategorized in the lexicon for an $\dot{\alpha}-N P$ complement. The dative clitic is still viewed as a substitute for $\dot{a}-N P$. A nonlexical dative is a dative clitic on a verb that does not subcategorize for $\dot{a}-N P$. Barnes does not give a precise syntactic criterion to distinguish between these two types of dative. She states: "though there are a few verbs whose status is problematic, for the most part the distinction is clear." In a footnote, the author refers to Barnes (1980) for discussion of these problematic cases (Barnes (1985: 160 and 192)). In this article, Barnes (1980: 247) argues that there is no syntactic criterion that allows to distinguish between lexical and nonlexical datives, since the lexicalization of the nonlexical dative clitic in (5) is perfectly acceptable for her informants.

$$
\begin{aligned}
& \text { Je leur cuis un gâteau. 'I bake a pie for them.' } \\
& \text { Je cuis un gâteau aux enfants. }
\end{aligned}
$$

However correct it may be that acceptability judgments on this type of sentences vary a lot, we do not think that this variation suffices to exclude the possibility of a syntactic criterion which would distinguish between lexical and nonlexical dative clitics. 
On the contrary, it is possible to establish this distinction on purely formal grounds when one takes into account the relationship between the other complements and $\dot{a}-N P$. As a matter of fact, sentences which exhibit a great deal of variation when the nonlexical dative clitic is lexicalized, are totally unacceptable when the direct object is pronominalized at the same time.

(6) a. *(Quant à un emploi,) j'en ai trouvé un à Théophile. '(As for a job,) I found one for Théophile.'

b. *(Ce pull,) le gosse l'a démoli à sa mère. '(That sweater,) the kid destroyed it on her mother'

c. *(Quant au gâteau,) j'en ai cuit un aux enfants.

'(As for the cake,) I baked one for the children'

Obviously, this construction is perfectly acceptable for lexical datives of transitive verbs.

(7) a. (Ce livre,) je le donne à Cunégonde.

'(This book,) I give it to Cunégonde.'

b. (Ce droit,) le gouvernement l'a reconnu aux ouvriers.

'(That right,) the government gave it to the workers.'

c. (Quant aux fleurs,) j'en vends beaucoup aux touristes.

'(As for flowers,) I sell a lot of them to tourists.

It is worth-while noting that a construction with clefting of the direct object does not give the same results. Rather, we again obtain a variation of acceptability.

(8) a. *C'est le pull que le gosse a démoli d̀ sa mère.

'It is the sweater the kid destrored on his mother.'

b. ?? C'est la jambe qu'on a cassée ì Gertrude.

'It is the leg they broke on Gertrude.'

c. C'est ce ton-là qu'il voulait à son roman.

'It is that measure he wanted for his novel.'

A second syntactic criterion that may serve to distinguish lexical and nonlexical datives straightforwardly is passivization. Ruwet (1982: 180) uses this operation in his criticism of the transformational derivation of a related type of sentences from deep structure sentential complements, but he does not draw the distinction that 
is of interest to us. ${ }^{2}$ Passivization of nonlexical dative clitic sentences yields unacceptable outputs.

(9) a. *? Un emploi lui a été trouvé. 'A job was found for him/her.' *Un emploi a été trouvé à Théophile.

b. *? Ce pull lui a été démoli par le gosse.

'That sweater was destroyed on him/her by the kid.'

* Ce pull a été démoli à Léontine.

c. *Un gâteau leur a été cuit. 'A cake was baked for them.' *Un gâteau a été cuit aux enfants.

Once again, lexical datives do not exhibit this characteristic. ${ }^{3}$

(10) a. Ce livre lui a été donné.

'That book was given to him/her.'

Ce livre a été donné à Cunégonde.

b. Ce droit leur a été reconnu.

'That right was given to them.'

Ce droit a été reconnu aux ouvriers.

c. Beaucoup de fleurs leur ont été vendues.

'A lot of flowers were sold to them.'

Beaucoup de fleurs ont été vendues aux touristes.

We do not have an explanation for the subtle contrast native speakers seem to perceive between some of the passive sentences with dative clitics and the sentences with a lexicalized dative in (9). Nevertheless, two syntactic criteria can be put forward to account for the distinction between lexical and nonlexical datives: first, the construction which lexicalizes the dative clitic and pronominalizes the direct object, and second passivization. One could easily object that these tests only distinguish lexical and nonlexical datives of transitive verbs. These criteria cannot be applied to datives of intransitive verbs and of verbs that select a prepositional complement. (cf. also ex. (4c).)

(11) a. Cela lui appartient. / Cela appartient à Frédéric. 'That belongs to him/her.' *Cela apparlient.

b. Fabrice lui lira dessus. 'Tabrice shot at him.' * Fabrice tira dessus au cavalier prussien. 
However, this is only a false problem since the status of the datives in these sentences is selfevident. In (11a), lexicalization of the dative clitic is perfectly possible. Since (5) shows that this is not a sufficient criterion, we have to turn to another test to make clear the status of the dative in this sentence. The criterion of necessity as applied in (1la) proves the lexical status of the dative independently, since nonlexical datives can always be freely deleted. In (11b and $c)$, the total unacceptability of $\dot{a}-N P$ shows the nonlexical character of the dative. In the next section, we will try to offer an alternative explanation for the variation in acceptability Barnes (1985) observes for nonlexical $\dot{a}-N P$.

\section{VARIATION IN ACCEPTABILITY: \\ SEMANTIC OR FORMAL ANALOGY?}

In the preceding section, we observed that the lexicalization of a nonlexical dative clitic is relatively unacceptable when the direct object is lexical and completely unacceptable when the direct object is pronominal. In order to complete this distribution, it may be worth-while noting that both elements can be pronominalized, showing their relative independence of one another.

(12) a. Je lui en ai trouvé un (, d'emplois). 'T found one for him/her.'

b. Le gosse le lui a démoli (, son pull).

'The kid destroyed it on him/her.'

This distribution of both lexical and pronominal direct objects and datives clearly shows the marginal status of nonlexical $\dot{a}-N P$. Nevertheless, the variation of acceptability should be explained. It does not seem possible to explain this variation on purely formal grounds. We will therefore offer a critical comment on Barnes' (1985) analysis, and try to provide for an alternative and simpler account of the same data.

Barnes (1985) uses the argument of semantic analogy in order to justify the relative unacceptability of the type of sentences in (4). According to her, lexical datives are marked as second objects of the verb, and as such are associated with the semantic characterization of 'theme'. Barnes suggests that the alternation between $\dot{a}-N P$ and $l u i$, and the fact that $\dot{a}$ marks thematicity, allows for a nonlexical $\dot{a}-N P$ which is analogously marked for theme. However 
vague this analogical explanation may be, even on a more formal level the idea of influence of a structure on another formally related construction cannot be excluded a priori. However, the syntactic constraint Barnes (1985: 181) formulates for this 'extended' $d-N P$ is much less plausible. In order to explain the unacceptability of $\grave{a}-N P$ in (13), Barnes (1985: 182 and 194) states a condition excluding the possibility of more than one occurrence of PP in French. ${ }^{4}$

(13) a. *Les gosses onl gribouillé sur tous les murs à Marie.

'The kids scribbled on all the walls (? on her.)'

b. *Elle a tiré dans le ventre à Jean. 'She shot him in the stomach.'

The nonexistence of such a principle is easy to prove.

(14) a. Chlöé a acheté une écharpe pP pour Nestor PP avec Clitandre. 'Chlöé bought a scarf for Nestor with Clitandre.'

b. Zöé a donné une rivière de perles pp à Aristide PP pour Melpomène.

'Zöé gave a necklace of pearls to Aristide for Melpomène.'

The constraint cannot even be generalized for nonlexical datives.

*? Les gosses ont dessiné des ânes sur tous les murs à Marie. 'The kids scribbled donkeys on all the walls for Marie.'

(?) Les gosses ont dessiné à Marie des ânes sur tous les murs.

For several speakers, the second sentence of (15) is considerably better than the first, although it is a little deviant.

Furthermore, Barnes (1985: 183) formulates semantic constraints on the 'extended' (nonlexical) $a-N P$. She is forced to invoke confusion with the (substandard) abnominal reading of $\dot{a}-N P$ to justify both the relative acceptability of (16) and the unacceptability of $(17)$.

?/OK On a cassé le bras à Jean. (Barnes (1985: (3+c)/(73)) 'They broke John's arm.'

?? Je refais ces reliures à Duval. (Barnes (1985: (56))

'T'm redoing these bindings for Duval.'

Finally, Barnes (1985) can only observe that malefactive datives are less acceptable than benefactives in a nonlexical $\dot{a}-N P$ context. This observation follows logically from the analysis we will present 
in the remainder of this paragraph. We will try to describe the same variation of acceptability as the one Barnes (1985) describes, since the judgments she advances are empirically wellfounded.

First, we will eliminate the cases where the nonlexical $\dot{a}-N P$ is a lexicalization of a clitic that has a relation of inalienable possession with the direct object. The near acceptability of these sentences as opposed to the other cases of nonlexical $a-N P^{5}$ can be attributed to this relation, which does not imply the adnominal reading. ${ }^{6}$

(18) a. (?) On a tordu le poignet d Pierre. 'They twisted Peter's wrist.' b. (?) On a tiré les oreilles à Marc. 'They pulled Marc's ears.'

The other cases of nonlexical $\dot{a}-N P$ can be explained by another type of analogy. The acceptability of nonlexical $\dot{a}-N P$ in these sentences parallels the acceptability of pour-NP in the same sentences for a majority of cases. The acceptability of these sentences is then a consequence of the polysemy of $\dot{a}$, a preposition that permits usages that are close to pour.

(19) a. ? Paul a cassé ces trois verres à Mariel pour Marie. 'Paul broke these three glasses on Marie.'

b. ? Ellle a démoli son pull à sa mèrel pour sa mère. 'She destroyed her sweater on her mother.'

(20) a. ?? Paul a fait une bronchite à sa mère/ pour sa mère. 'Paul got bronchitis for his mother.'

b. *Paul a attrapé une bronchite à sa mèrel pour sa mère. 'Paul caught bronchitis for his mother.'

c. "Paul a bu trois pastis $\dot{a}$ / pour Marie sans dire merci. 'Paul drank three pastis on Marie without saying thank you.'

The following sentences are all slightly deviant for Barnes' (1985) informants. It comes as no surprise that the version with pour is perfectly acceptable.

(21) a. (?) Elle tricote un pull au bébé/ OK pour le bébé. 'She is knitting a sweater for the baby.'

b. (?) Il choisit des bagues ì sa femme / OK pour sa femme. 'He chooses rings for his wife.'

c. (?) Paul a joué le 5 à Marie dans la dernière course / OK pour Marie.

'Paul bet on number five for Marie in the last race.' 
However, some cases seem to falsify the observation that accepta. bility of $\dot{a}-N P$ parallels acceptability of pour-NP. The preposition pour is acceptable in the following sentences, but $\dot{a}-N P$ is excluded.

(22) a. ? ? J'ai rajeuni des/ces plantes à Paul/ OK pour Paul.

' $I$ rejuvenated these/some plants for Paul.'

b. ?? Je refais ces reliures à Duval.

'I'm redoing these bindings for Duval.'

We agree with Barnes (1985: 185) who attributes this unacceptability to a confusion of the nonlexical $\dot{a}-N P$ complement with the adnominal reading of $\dot{a}-N P$. Admittedly, this confusion with the adnominal reading is not always clear, and semantic factors seem to influence acceptability judgments. Barnes (1985) does not offer an explanation for the difference in acceptability of the two following sentences.

? J'ai corrigé ces devoirs à Jean. (Barnes (1985: (52))

'I corrected these assignments for/of Jean.'

?? J'ai corrigé ces épreuves à Jean.

'I corrected these proofs for/of Jean.'

A possible explanation for this opposition could be the observation that an adnominal reading is more readily available in (24), because the semantic context suggests that the 'proofs' have also been produced by 'Jean'. Hence confusion as in (22) is possible. On the contrary, in (23), the 'assignments' are semantically assimilated to something 'external' that is 'imposed on' 'Jean'. The possible possessive link for the informant who is looking for an interpretation, is intuitively more clear in (24). This brings about a confusion between the adnominal reading and the 'independent' $\dot{a}-N P$ reading. The same line of reasoning can explain why the sentences of (19) are better. Quantification of the NP (trois) in (19a) and the presence of two possessive markers in (19b) render an adnominal reading of $\dot{a}-N P$ rather difficult. As a result, a reading of $\dot{a}-N P$ with a meaning close to that of pour-NP is the only interpretation left. Note that this analysis also accounts for the opposition in (15): quantification of PP notwithstanding, there is a strong tendency to interpret $d-N P$ as a complement of PP in (15a). The position of 
$\grave{a}-N P$ in (15b) excludes this reading, and the sentence is nearly acceptable.

Another problem for this analysis is the following sentence, where pour-NP is unacceptable.

“Le capitaine trouvait d̀ l'alchimiste l'air soucieux et fatigué." (M. Yourcenar, L'œuvre au Noir, p. 137)

But this sentence can be explained by the idiomaticity of this specific meaning of lui trouver NP. Clefting is not possible for NP in (25), but it is in (26b) and (8).

(26) a. *C'est l'air soucieux et fatigué que le capitaine trouvait à l'alchimiste.

b. ? C'est un emploi que j'ai trouvé à Théophile.

This argument is not sufficient, since (8) shows a variation of acceptability for nonlexical $\dot{a}-N P$ in this construction. However, pronominalization of both elements as in (12) is not possible for (26). This proves convincingly, we feel, the idiomatic status of lui trouver $N P$ with the meaning it has in (26).

* Le capitaine le lui trouvait, (l'air soucieux....).

This analysis seems to be able to draw the basic distinction between acceptable and unacceptable nonlexical $\dot{a}-N P$. Other semantic factors probably play a role in the acceptability of these sentences. Moreover, a more extensive test with native speakers should make clear whether these differences are really pertinent. The distribution of nonlexical clitics and $\dot{\alpha}-N P$ clearly shows that the $\dot{a}-N P$ construction is only marginally possible. The conditions on its varying acceptability can be stated in a relativaly precise and simple way. In the next paragraph, we will try to define the status of the nonlexical dative clitic in the sentence.

\section{THE SYNTACTIC STATUS OF THE NONLEXICAL DATIVE}

The marginal character of nonlexical $\dot{a}-N P$ justifies treating the nonlexical dative clitic as an optional morpheme on the verb. In terms of Blanche-Benveniste et alii (1984), one could say that there is no real 'proportional link' between the nonlexical clitic and 
the nonlexical $\grave{a}-N P$. Blanche-Benveniste et alii (1984: 72) observe that this dative clitic shows a relation of 'solidarity' with the function of direct object. They only examine cases of 'inalienable possession' as in (28).

$$
\text { Je lui casse la jambe. }
$$

The authors claim that the impossibility of (29) suffices to prove this 'solidarity' with the function of direct object.

$$
\text { *Je lui casse. }
$$

However, it seems that this test is a necessary but not sufficient condition for the 'solidarity' between the nonlexical dative clitic and the function of direct object. For some lexical dative clitics, suppression of the direct object also gives an ungrammatical result.

(30) a. Ludwig consacra une symphonie à un général corse.

'Ludwig dedicated a symphony to a Corsican general.'

b. *Ludwig lui consacra.

A sufficient argument to prove this 'solidarity' between the nonlexical dative clitic and the function of direct object is the criterion of passivization as we used it in $\S 1$ (9). If the dative clitic was only linked to the verb, it should be possible to express it in the passive construction of the same verb. (9) and (31) show that this is not the case, so we can conclude that the 'solidarity' really exists.

$$
\text { * La jambe lui a été cassée. 'His leg was broken (? on him.)' }
$$

For intransitive verbs that have a nonlexical dative clitic, the solidarity is established with a PP. The unacceptability of these sentences without PP is a necessary and sufficient argument for the solidarity between these two elements, since verbs that subcategorize for both a lexical dative and a (nondeletable) PP of the locative type do not exist in French.

(32) a. Les enfants lui ont gribouillé sur tous les murs.

'The kids scribbled on all the walls (? on her.)'

* Les enfants lui ont gribouillé.

b. Fabrice lui lira dessus. 'Fabrice shot at him.'

* Fabrice lui tira. 
In order to determine the exact value of the notion of solidarity, it may be useful to compare the nonlexical dative clitic with other clitics that display a similar behaviour. Blanche-Benveniste et alii (1985) analyze the nonlexical dative clitic along the same lines as the clitics en of (33a and $b$ ). In their analysis, the nonlexical dative clitic belongs to the valency of the verb, the clitic en of (33a) to the valency of the $A P$, and the clitic en of $(33 b)$ to the valency of a semantic subtype of NP.

(33) a. J'en suis fier. 'I am proud of it.'

b. J'en connais le prix/ une partie. 'I know the price/part of it.' However, there is a crucial difference between the clitic en in (33) and the nonlexical dative clitic. The adnominal or adjectival complement and the NP or AP cannot be pronominalized at the same ime, because two clitic pronouns cannot have a dependency relation tn French.

(i34) a. *Je l'en suis.

b. *Je l'en connais.

On the contrary, as shown in (12), the nonlexical dative clitic and the direct object it is linked with ean both be pronominalized. This difference seems to show that two types of solidarity can be distinguished. In (33), the dependency relation holding between the clitic and NP or AP is such that the clitic en is subordinated to the NP or AP that selects it. In this case, we can speak of discontinuous constituents. The link between the nonlexical dative clitic and necessary complement of the verb (direct object or PP) is a relation of solidarity, but not of discontinuity.

\section{AMBIGUITY BETWETN LEXICAL AND NONLEXICAL DATIVES}

It is a well-known fact that dative clitics of certain French verbs are a mbiguous between a Beneficiary and a Source reading.

(35) a. Je lui ai acheté cette voiture.

'I bought that car for/ from him/ her.'

b. Je lui ai pris ce disque.

'I took that record for/ from him/ her.' 
The analysis presented here provides for a formal explanation of this interpretive ambiguity. When applied to (35), both criteria ${ }^{7}$ developed in $\S 1$ only select the Source interpretation for the dative.

(36) a. Je l'ai acheté àd, de mon frère. 'I bought it from my brother.'

b. Je l'ai pris à Donatienne. 'I took it from Donatienne.'

(37) a. Cette voiture lui a été achetée par Guillaume.

'That car was bought from him by Guillaume.'

b. Ce disque lui a été pris hier soir.

'That record was taken from her yesterday evening.'

Since only the lexical dative can occupy different positions in the sentence, we can reasonably conclude that the dative interpreted as Source is a lexical dative. According to the criteria defined above, a nonlexical dative can only appear in an active structure as (35). ${ }^{8}$ Consequently, we can say that verbs as acheter, prendre are characterized by the selection of both a lexical (Source) and a nonlexical (Beneficiary) dative. In (35), this structural difference is neutralized, resulting in an interpretive ambiguity.

\section{CONCLUSION}

The possibility for a dative to occur in different sentence structures seems to offer an interesting tool for distinguishing between lexical and nonlexical datives. A lexical dative can freely occur in any sentence structure since it is part of the lexical definition of the verb. A nonlexical dative is only perfectly acceptable as a clitic on the verb. This clitic does not have the status of a lexical argument of the verb: it only has a link of solidarity to the direct object or the PP selected by the verb. The varying acceptability of lexicalized nonlexical datives can be explained by the interaction of both formal and semantic factors. Finally, this analysis allows to draw a formal distinction in an interesting case of interpretive ambiguity of the dative clitic.

Address of the author: Johan Rooryck

Departement Iinguistiek

Faculteit van de Letteren en de

Wijsbegeerte

Blijde-Inkomststraat 21

B-3000 Leuven (Belgium) 


\section{NOTES}

* I would like to thank Ludo Melis, Karel Van den Eynde and Serge Verlinde for valuable discussions, although they do not necessarily agree with what I say in this paper. Thanks go also to the National Fund for Scientific Research (Belgium) for financial support, and to Geert Adriaens for correcting my English.

1 In this paper, we will not discuss the so-called 'ethical dative'. Although this ethical dative is also nonlexicalizable dative clitic, it can be distinguished from the nonlexical dative on several grounds. Unlike the nonlexical dative, the ethical dative is limited to first and second person and can be redoubled. Moreover, it can cooceur with a nonlexical dative.

Avez-vous vu comme je te vous lui ai craché à la figure?

(Victor Hugo, Les misérables 1, 5, 13 quoted by Grevisse (1980: §1063)).

A further difference is that nonlexical datives can only be combined with 'active' or 'nonstative' verbs (Donaldson (1973)), or 'phase 2' verbs in the terminology of Blanche-Bonveniste et alii (1984: 74). No such constraint exists for the ethical dative. (See also Leclère (1976.)

* Je lui regarde la figure. 'I see his face.'

Tu me regardes co drôlo de bonhomme-là? 'Do you see that strange guy ?'

2 Ruwet (1982: 172) distinguishes an 'epistemic dative' for some verbs that can have sentential complements as well as a construction with direct object and dative.

a. Je lui croyais une maîtresso dans chaque port.

Je croyais qu'il avait une maîtresse dans chaque port.

b. Le gouvernement a reconnu le droit de grève aux ouvriers.

Le gouvernement a reconnu que les ouvriers ont le droit de grève.

The notion of 'epistemic dative' covers a subtype of lexical dative as well as a subtype of nonlexical dative. In (a), the dative clitic cannot be lexicalized nor can it remain after passivization. In (b), lexicalization and pronominalization are equally possible, and the dative remains after passivization. The dative in (a) is nonlexical, the dative in (b) lexical.

${ }^{3}$ Passivization also secms to distinguish lexical and nonlexical datives in Dutch. (K. Van den Eynde, personal communication.)

a. Ik heb hem dat boek gegeven. 'I gave him that book.'

b. Ilk heb hem dat boek gekocht.

'I bought him that book.'

Dat boek werd hem gegeven.

'That book was given to him.'

* Dat boek werd hem gekocht.

'That book was bought to him.'

${ }^{4}$ Barnos (1985: 194 note 23) stipulates this condition as follows: "T.e. $\mathrm{VP} \rightarrow \mathrm{V}-(\mathrm{NP})-(\mathrm{PP})$, as opposed to $\mathrm{S} \rightarrow \mathrm{NT}-\mathrm{VP}-(\mathrm{PP})^{*}$, where * indicates the possibility of more than one occurrence of PP." Note that some of the examples the author gives herself blatently contradict this condition, for instance $(21 \mathrm{c})=$ Barmes $(1985:(22 \mathrm{~d}))$.

${ }^{5}$ However, as Barnes (1985) points out, datives of the inalienable possession type are part of the nonlexical datives in general. The criteria developed in $\S \mathrm{l}$ can suffico to prove this point.

* Le poignet lui a été tordu

* On l'a tordu à Pierre.

The possibility of questioning these lexicalized nonlexical datives is linked to the degree of acceptability of full lexicalization:

A qui a-t-on tordu le poignet? (cf. 18a supra)

?? A qui as-tu trouvé un emploi ? (cf. 4a supra) 
6 The possibility of an adnominal reading can be tested by the application of clefting on the complex NP. Since clefting is not possible for the complex NP in (18), $a-N P$ cannot be considered an adnominal complement.

I8a') * C'est le poignet à Pierre qu'on a tordu.

$\left.18 \mathrm{~b}^{\prime}\right){ }^{*}$ Ce sont les oreilles a Jacques qu'on a tirées.

On the other hand, for (22), clefting of the complex NP is acceptable.

22a') Ce sont ces plantes à Paul que j'ai rajeunies.

(22b') Ce sont ces reliures à Duval que j'ai refaites.

This tentative explanation has to be taken as an interpretive analogy between $\grave{a}-N P$ and pour-NP, not as a semantic equivalence.

7 Questioning and clefting of the dative in (36) also yields the Source interpretation.

A qui as-tu acheté cette voiture?

C'est à lui que j'ai acheté une voiture.

${ }^{8}$ This affirmation is restricted to the cases where the nonlexical dative clitic is linked to the direct object. Of course, a nonlexical dative clitic is possible in a passive structure when linked to a PP. Consider the following contrast.

* Ce costume lui a été taillé dans les règles de l'art.

Ce costume lui a étó taillé sur mesure.

$I_{n}$ the first sentence, the nonlexical dative clitic cannot be linked to the $P P$, since this $P P$ is not selected by the lexical definition of the verb. In the second sentence and in the following one, PP is selected by the verb.

Une balle lui a été tirće dans le ventre.

\section{BIBLIOGRAPHY}

Barnes, Betsy. 1980. "The Notion of Dativo in Linguistic Theory and the Grammar of French." Linguisticae Investigationes IV, 245-292.

Barnes, Betsy. 1985. "A Functional explanation of Fronch Nonlexical Datives." Studies in Language 9.2, $159-195$.

Blanche-Benveniste, Claire, José Deulofeu, Jean Stéfanini \& Karel Van den Eynde. 1984. Pronom et Syntaxe: l'approche pronominale et son application en français. Paris: Selaf.

Donaldson, Weber. 1973. French Reflexive Verbs. The Hague: Mouton.

Grevisse, Maurico. 1980. Le bon usage. Gembloux: Duculot.

Leclère, Christian. 1976. "Datifs syntaxiques et datif éthique." In: JeanClaude Chevalier \& Maurice Gross (eds) Méthodes en grammaire française. Paris: Klincksiock, $73-96$.

Leclère, Christian. 1978. "Sur une classo de verbes datifs." Langue française $39,66-75$.

Ruwet, Nicolas. 1982. "Lo datif épistémique on français et la condition d'opacité do Chomsky." In: Grammaire des insultes. Paris: Le Seuil, $172-204$. 